\title{
SYNTHESIS, CHARACTERIZATION AND CRYSTAL STRUCTURE OF BIS-(2-HYDROXYBENZALDEHYDE)DIAMINOGUANIZONE
}

\author{
Diana Dragancea**, Vladimir B. Arion ${ }^{\mathrm{b}}$, Sergiu Shova ${ }^{\mathrm{c}}$ \\ ${ }^{a}$ Laboratory of Coordination Chemistry, Institute of Chemistry, Academy of Sciences, \\ Academiei str. 3, MD-2028, Chisinau, Moldova, \\ ${ }^{b}$ Institute of Inorganic Chemistry, Faculty of Chemistry, University of Vienna, Vienna, Austria \\ 'Department of Chemistry, Moldova State University, Chisinau, Moldova \\ *ddragancea@mail.md, Tel: +37322 739611, Fax: +37322 739954
}

\begin{abstract}
The new ligand, bis(2-hydroxybenzaldehyde)diaminoguanizone (1) has been synthesized and characterized by elemental analysis, IR and ${ }^{1} \mathrm{H}$ NMR spectroscopies. The crystal structure of the compound was determined by $\mathrm{X}$-ray diffraction. The ligand $\mathrm{C}_{15} \mathrm{H}_{15} \mathrm{~N}_{5} \mathrm{O}_{2} \cdot \mathrm{C}_{2} \mathrm{H}_{5} \mathrm{OH}$ crystallizes in the monoclinic space group $P 2_{1} / c$ with unit cell parameters $a=8.9102(3), b=10.0357(3), c=19.7618(6) \AA, \beta=98.385(2)^{\circ}, Z=4, V=1748.21(9) \AA^{3}, R 1=0.040$. The amino form of the ligand adopts a planar conformation stabilized by two intramolecular hydrogen bonds of the type $\mathrm{O}-\mathrm{H} \cdots \mathrm{N}$, in which the $\mathrm{H}$ atoms of the central amino group are directed to the lone-pair regions of the azomethine nitrogen atoms.
\end{abstract}

Keywords: Schiff base, guanidine, X-ray diffraction

\section{Introduction}

Carbohydrazones and thiocarbohydrazones are the next homologues of semicarbazones and thiosemicarbazones, which are well-known for their biological activity. Owing to the presence of different kinds of potential donor sites they are interesting ligand species capable of generating mononuclear, dinuclear and even tetranuclear complexes [1-4]. X-ray diffraction structures of these compounds revealed the presence of different conformers (cis, cis or cis, trans) differing in position of hydrazine group with respect to $\mathrm{C}=\mathrm{X}(\mathrm{X}=\mathrm{S}, \mathrm{O})$.

Compared to studies on symmetrical Schiff bases of thiocarbohydrazones and carbohydrazones with salicyladehyde $[5,6]$, no data concerning the crystal structure of the title compound has been reported so far, although the synthesis of this Schiff base has been well documented [7]. Several metal chelates of bis(salicylidene) thiocarbohydrazone and carbohydrazone have been studied [8-9]. Complexation behavior of the nitrogen analogue 1 toward metal ions would be an interesting object of study. The present report can also be considered as an extension of investigations on salicylaldehyde aminoguanizone and its metal complexes reported elsewhere $[10,11]$. In order to study the complexation behavior of 1,5-(2-hydroxybenzaldehyde)diaminoguanizone with first and second row transition metal ions, we synthesized the ligand $\mathbf{1}$ and determined its crystal structure.

\section{Materials and physical measurements}

2-Hydroxybenzaldehyde (Aldrich) and diaminoguanidine hydrochloride (Aldrich) were used as received. Elemental analyses were carried out using Vario EL III CHNOS Elemental Analyzer. Infrared spectra were recorded on a Perkin-Elmer FTIR spectrophotometer. NMR spectra were performed on a Bruker 80 spectrometer in DMSO- $d_{6}$ solution using TMS as internal reference.

\section{X-ray crystallography}

The data collection was done on a Bruker X8 APEX II CCD diffractometer using graphite monochromated $\mathrm{MoK}_{a}$ radiation $(\lambda=0.71073 \AA)$ at $100(2) \mathrm{K}$. The data were processed using SAINT software [12]. The structure was solved by direct methods and refined by full-matrix least-squares techniques. Non-hydrogen atoms were refined with anisotropic displacement parameters. $\mathrm{H}$ atoms were placed at calculated positions and refined as riding atoms in the subsequent least-squares model refinements.

\section{Results and Discussion}

Selected bond lengths $(\AA)$ and angles (deg) are listed in Table 1. As shown in Figure 1, the molecule 1 adopts a planar conformation which is stabilized by two intramolecular hydrogen bonds $\mathrm{O} 1-\mathrm{H}^{\cdots} \mathrm{N} 1\left[\mathrm{O} 1-\mathrm{H}\right.$ 0.891. $\mathrm{H}^{\cdots} \mathrm{N} 11.873$, $\mathrm{O} 1 \cdots \mathrm{N} 12.665 \AA, \angle \mathrm{O} 1-\mathrm{H}^{\cdots} \cdots \mathrm{N} 11^{\left.147.09^{\circ}\right]}$ and $\mathrm{O} 2-\mathrm{H} \cdots \mathrm{N} 5[\mathrm{O} 2-\mathrm{H} 0.912 . \mathrm{H} \cdots \mathrm{N} 51.808, \mathrm{O} 2 \cdots \mathrm{N} 52.646 \AA, \angle \mathrm{O} 2-\mathrm{H} \cdots \mathrm{N} 5$ $\left.151.75^{\circ}\right]$, as also reported for sulfur and oxygen analogs $[8,9]$ The $\mathrm{H}$ atoms of the central amino group (the hydrogens attached to N3) are directed to the lone-pair regions of the azomethine nitrogen atoms N1 and N5. Similar situation was found in 1,3-diaminoguanidinium cation [13], where the corresponding $\mathrm{H}$ atoms of the central amino group were found to be directed to the lone-pairs of the terminal aminogroups. The N4-C8 bond of 1.3179(19) $\AA$ is shorter than N2-C8 bond of 1.3591(19) $\AA$ as a result of proton migration from N4 to the N3 atom. Recent theoretical studies on electron 
delocalization in diaminoguanidine [14] showed larger stability of the amino form over the other possible tautomeric forms. The X-ray data were deposited at the Cambridge Crystallographic Data Center No. CCDC 702169.

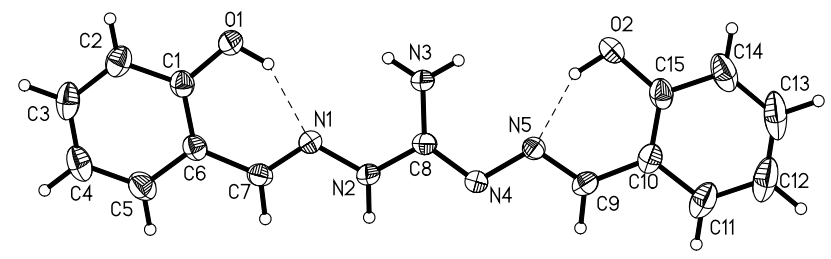

Fig. 1 The molecular structure of $\mathbf{1} \cdot \mathrm{EtOH}$. Dashed lines denote intramolecular hydrogen bonds.

Selected bond lengths $(\AA \AA)$ and bond angles (deg)

\begin{tabular}{|llllllll|}
\hline N1-C7 & $1.282(2)$ & C8-N4 & $1.318(2)$ & N3-C8-N4 & $126.9(1)$ & C8-N2-N1 & $116.1(1)$ \\
N1-N2 & $1.367(2)$ & N4-N5 & $1.389(2)$ & N4-C8-N2 & $114.5(1)$ & C8-N4-N5 & $113.4(1)$ \\
N2-C8 & $1.359(2)$ & N5-C9 & $1.288(2)$ & N3-C8-N2 & $118.7(1)$ & & \\
C8-N3 & $1.333(2)$ & & & & & & \\
\hline
\end{tabular}

\section{Experimental}

2-Hydroxybenzaldehyde (1.21 g, $10 \mathrm{mmol})$ in EtOH $(20 \mathrm{ml})$ was added to diaminoguanidine monohydrochloride $(0.62 \mathrm{~g}, 5 \mathrm{mmol})$ and $\mathrm{Na}_{2} \mathrm{CO}_{3}(0.26 \mathrm{~g}, 5 \mathrm{mmol})$ in $\mathrm{H}_{2} \mathrm{O}(5 \mathrm{ml})$. The solution obtained was refluxed for $1 \mathrm{~h}$. The yellow solid precipitated on cooling the solution was filtered off, washed with EtOH, dietyl ether and dried in air. X-ray diffraction quality single crystals of bis(2-hydroxybenzaldehyde)diaminoguanizone were grown in ethanol. Yield: $1.01 \mathrm{~g}, 70 \%$; m. p. $205^{\circ} \mathrm{C}$. Anal. Calcd for $\mathrm{C}_{15} \mathrm{H}_{15} \mathrm{~N}_{5} \mathrm{O}_{2}(\%)$ : C, 60.60; H, 5.09; N, 23.56. Found: C, 60.08; H, 5.25; N, 23.44. IR $\left(\mathrm{cm}^{-1}\right)$ : $3467(\mathrm{NH}), 1622(\mathrm{C}=\mathrm{N}), 1262(\mathrm{C}-\mathrm{N}) .{ }^{1} \mathrm{H}$ NMR $(\delta: \mathrm{ppm}): 8.29(\mathrm{~s},-\mathrm{CH}=), 6.73-7.57(\mathrm{~m}, 8 \mathrm{H}$, aromatic ring protons).

Crystal Data and Details of Data Collection for $\mathbf{1}$.

Table 2

$\begin{array}{ll}\text { Empirical formula } & \mathrm{C}_{17} \mathrm{H}_{21} \mathrm{~N}_{5} \mathrm{O}_{3} \\ \mathrm{fw} & 343.39 \\ \text { space group } & \text { monoclinic } \\ \text { space group } & P 2_{1} / c \\ a, \AA & 8.9102(3) \\ b, \AA & 10.0357(3) \\ c, \AA & 19.7618(6) \\ \beta, \mathrm{deg} & 98.385(2) \\ V, \AA^{3} & 1748.21(9) \\ \mathrm{Z} & 4 \\ \rho_{\text {caldd }} \mathrm{g}^{3} \mathrm{~cm}^{-3} & 1.305 \\ \mathrm{crystal} \mathrm{size}, \mathrm{mm}^{3} & 0.35 \times 0.25 \times 0.22 \\ T, \mathrm{~K} & 100(2) \\ R 1^{a} & 0.0402 \\ w \mathrm{R}^{b} & 0.1001 \\ \mathrm{GOF}^{c} & 0.976\end{array}$

${ }^{a} R 1=\sum|| \mathrm{Fo}|-| \mathrm{Fc}|| \sum|\mathrm{Fo}|,{ }^{b} w R 2=\left\{\sum\left[w\left(\mathrm{Fo}^{2}-\mathrm{Fc}^{2}\right)^{2}\right] / \sum\left[w\left(\mathrm{Fo}^{2}\right)^{2}\right]\right\}^{1 / 2} .{ }^{\mathrm{c}} \mathrm{GOF}=\left\{\sum\left[w\left(\mathrm{Fo}^{2}-\mathrm{Fc}^{2}\right)^{2}\right] /(\mathrm{n}-\mathrm{p})\right\}^{1 / 2}$, where $n$ is the number of reflections and $p$ is the total number of parameters refined.

\section{Acknowledgements}

D.D. acknowledges the support from the Supreme Council for Science and Technological Development, Academy of Sciences of Moldova (Award No. 08.819.05.09A).

\section{References}

[1]. Rana, A.; Dinda, R.; Sengupta, P.; Chosh, S.; Falvello, LR. Polyhedron. 2002, 21, 1023-1030.

[2]. Duan, CY.; Liu, ZH.; You, XZ.; Xue, F.; Mak, TCW. Chem. Commun. 1997, 381-382.

[3]. Bacchi, A.; Bonini, A.; Carcelli, M; Ferraro, F.; Leporati, E.; Pelizzi, C.; Pelizzi, G. Dalton Trans. 1996, 26992704. 
[4]. Manoj, E.; Prathapachandra Kurup, MR.; Fun, H.-K. Inorg. Chem. Commun. 2007, 10, 324-328.

[5]. Yanping, R.; Rongbin. D.; Liufang, W.; Jigui, W. Synth. Commun. 1999, 29, 613-617.

[6]. Dan, BJ.; Seth, S.; Cakraborty, S. Acta Cryst. 1987, C43, 1114-1116.

[7]. Montana Gonzales, MT.; Gomez Ariza, J.L. Anal. Quim. 1984, V. 80, 129-133.

[8]. Bustos, C.; Burckerhardt, O.; Scharebler, R., Carillo D., Arif, AM., Cowley, AH. Inorg. Chem. 1990, 29, 39964001.

[9]. Dragancea, D.; Arion, V.B.; Shova, S.; Rentschler, E.; Gerbeleu, N.V. Angew. Chem. Int. Ed. 2005, 44, $7938-7942$.

[10]. Ревенко, М. Д., Гэрбэлэу, Н. В., Волков, А. В. Ж. Неорг. Хим. 1975, т.20, № 5, с. 1417-1420.

[11]. Chumakov, Yu. M., Tsapkov, VI., Bocelli, G. et al. Crystallogr. Rep., 2006, Vol. 51, No. 1, pp. 60-67.

[12]. SAINT-Plus, version 7.06a and APEX2; Bruker-Nonius AXS Inc.: Madison, WI, 2004.

[13]. Cromer, D.T.; Hall, J.H.; Lee. K.-Y.; Ryan, R.R. Acta Cryst. 1988, C44, 2206-2208.

[14]. Prasad V.; Bharatam P.I. J. Comput. Chem. 2006, 27, 334-343. 